\title{
ANALISIS EFISIENSI HARGA DAN BIAYA USAHATANI CABAI MERAH (CAPSIUM ANNUUM L) DI KECAMATAN WULUHAN KABUPATEN JEMBER
}

\author{
Nihliatun Ni'mah ${ }^{1}$, Yuli Hariyati ${ }^{2}$, Titin Agustina $^{3}$ \\ Agribisnis, Universitas Jember \\ E-mail: Nihliatunnimah@gmail.com
}

\begin{abstract}
The productivity level of red chili in Wuluhan Sub-district in 2010 until 2015 has fluctuated. The level of productivity in red chili commodities in Wuluhan Sub-district is estimated to be influenced by several factors of production (fertilizer, pesticide, labor) and planting season. Some problems experienced by red chili farmers in Wuluhan Sub-district apart from productivity side of unstable but also from unstable selling price side. This research aims to determine (1) the influence of factors of production and planting season on productivity level of red chillies in Wuluhan Sub-district Jember District; (2) the efficiency of the price of the use of production factors at red chili farming in Wuluhan Sub-district, Jember District; (3) cost efficiency at red chili farming in Wuluhan Sub-district, Jember district. Location of research conducted by method of Purposive Method that is determination of research location done intentionally. Data collection methods used for primary data collection is the method of interview and questionnaire (questionnaire) while the data collection method used for secondary data collection is a documentation technique. The analytical tools used include: Cobb-Douglas production function, price efficiency and cost efficiency. The results showed that (1) production factors of pesticide, labor and planting season significantly affect productivity level; (2) The use of fertilizer, pesticide and labor production factor has not reached the price efficiency because the ratio between NPMxi and Pxi is more than one; (3) the use of cost is efficient, the business is run profitable and feasible to cultivate.
\end{abstract}

Keywords: Usahatani cabai merah, produktivitas, dan efisiensi.

\section{PENDAHULUAN}

Cabai merah merupakan komoditas hortikultura yang memiliki peluang ekonomi yang besar untuk dikembangkan karena permintaannya tinggi di Indonesia. Masyarakat Indonesia menggunakan cabai sebagai bumbu masakan (Imtiyaz, 2017). Konsumsi perkapita dalam rumah tangga untuk komoditas cabai merah masyarakat Indonesia tinggi. Kebutuhan cabai untuk kota-kota besar yang berpenduduk satu juta atau lebih sekitar 800.000 ton/tahun atau 66.000 ton/ tahun. Kebutuhan cabai meningkat sekitar $10-20 \%$ saat musim hajatan atau hari besar ( Anwarudin, 2015).

Cabai turut menyumbang besarnya inflasi bahan makanan yang terjadi bagi perekonomian di Indonesia (Nauly,2016). Pasokan yang kurang menyebabkan harga cabai melonjak tinggi sehingga menimbulkan inflasi (Surya,2015). Salah satu penyebab tidak tersedianya cabai sepanjang tahun adalah gagal panen karena perencanaan budidaya yang kurang baik .

Jawa Timur merupakan wilayah sentra budidaya ke 4 di Indonesia dengan rata-rata luas panen selama 5 tahun antara tahun 2010-2014 adalah sebesar 13.993,00 Ha. Kabupaten Jember merupakan salah satu kabupaten di Provinsi Jawa Timur yang membudidayakan cabai merah cukup tinggi di bandingkan kabupaten-kabupaten lainnya. Kecamatan di Kabupaten Jember dengan tingkat produksi dan luas panen cabai merah tertinggi adalah Kecamatan Wuluhan. Tingkat produktivitas usahatani cabai merah di Kecamatan Wuluhan mulai tahun 2010 sampai 2015 mengalami fluktuasi. Tahun dengan tingkat produktivitas terendah adalah tahun 2012 sebesar 10,91 Kw/Ha dan tahun 
dengan tingkat produktivitas tertinggi adalah tahun 2015 dengan tingkat produktivitas sebesar 105,99 Kw. Rata-rata produktivitas cabai merah Kecamatan Wuluhan sebesar 45,05 Kw/Ha dan Kabupaten Jember sebesar $51,378 \mathrm{Kw} / \mathrm{Ha}$. Hal tersebut menunjukkan bahwa tingkat rata-rata produktivitas cabai merah mulai tahun 2010 sampai dengan 2015 Kecamatan Wuluhan lebih kecil dibandingkan Kabupaten Jember.

Tinggi rendahnya produksi yang dihasilkan sangat dipengaruhi oleh penggunaan faktor produksi (Pranata,2016). Faktor produksi tenaga kerja dan pupuk kandang berhubungan positif dan berpengaruh nyata terhadap hasil produksi cabai merah, sedangkan pupuk NPK mutiara memiliki hubungan yang negatif dan berpengaruh nyata terhadap hasil produksi cabai merah (Triwidiyaningsih,2011). Faktor produksi luas lahan, bibit, tenaga kerja, pupuk, dan pestisida berpengaruh nyata terhadap hasil produksi cabai merah (Siahaan, 2015)

Tingkat produktivitas komoditas cabai merah di Kecamatan Wuluhan diperkirakan dipengaruhi oleh beberapa faktor produksi. Umumnya petani di Kecamatan Wuluhan menggunakan pupuk secara berlebihan dan menggunakan pestisida yang terkadang tidak sesuai dengan kondisi yang ada di lahan. Hal tersebut menyebabkab terjadinya penurunan produktivitas cabai merah. Petani seringkali mengalami kesulitan untuk mendapatkan tenaga kerja saat musim panen tiba sehingga proses pemanenan tidak optimal. Banyak petani di Kecamatan Wuluhan menanam cabai pada saat musim hujan. Berbagai penyakit yang menyerang tanaman cabai berkembang sangat pesat pada saat musim hujan seperti penyakit yang disebabkan baik oleh jamur maupun bakteri (Azzamy, 2016).

Beberapa masalah yang dialami petani cabai merah di Kecamatan Wuluhan selain dari sisi produktivitas yang tidak stabil tetapi juga dari sisi harga jual yang tidak stabil. Naik turunnya harga cabai merah di pasar sulit untuk diprediksi. Tahun 2015 harga terendah terjadi pada bulan Oktober seharga Rp 7.972/Kg dan harga tertinggi terjadi pada bulan Januari seharga $\mathrm{Rp} \quad 37.278 / \mathrm{Kg}$ (BPS Kabupaten Jember, 2016).
Adapun tujuan dari penelitian ini adalah untuk mengetahui faktor-faktor yang mempengaruhi tingkat produktivitas, efisiensi harga masing-masing penggunaan faktor produksi dan efisiensi biaya pada usahatani cabai merah di Kecamatan Wuluhan Kabupaten Jember agar tercapai pengembangan usahatani cabai merah. Melalui peningkatan produktivitas dan efisiensi di Kecamatan Wuluhan Kabupaten Jember.

\section{METODE PENELITIAN}

Metode penentuan daerah penelitian berdasarkan metode purposive method. Purposive Method adalah penentuan lokasi penelitian dilakukan secara sengaja. Daerah yang dipilih sebagai daerah penelitian adalah Desa Ampel Kecamatan Wuluhan karena merupakan desa dengan tingkat luas panen tertinggi di Kecamatan Wuluhan.

Metode yang digunakan dalam penelitian ini adalah metode analitik dan deskriptif. Metode analitik digunakan untuk menguji hipotesis-hipotesis dan mengadakan interpretasi yang lebih dalam tentang hubungan-hubungan variabel. Metode deskriptif bertujuan untuk membuat deskripsi, gambaran atau lukisan secara sistematis, faktual dan akurat mengenai fakta-fakta, sifat-sifat hubungan antar fenomena yang diselidiki (Martono, 2015).

Metode pengambilan contoh menggunakan teknik acak sederhana (simple random sampling). Metode yang digunakan untuk menentukan jumlah sampel adalah menggunakan rumus Slovin dengan batas kesalahan $15 \%$. Jumlah sampel minimal yang terpilih adalah sebanyak 37 petani cabai merah, dari populasi sejumlah 225 petani cabai merah. Sampel yang digunakan dalam penelitian ini adalah 39 petani cabai merah.

Metode pengumpulan data yang digunakan untuk pengumpulan data primer adalah metode wawancara dan kuisioner (angket). Pengumpulan data dilakukan dengan melakukan wawancara langsung kepada responden dengan menggunakan kuisioner sebagai panduan wawancara. Metode pengumpulan data yang digunakan untuk pengumpulan data sekunder adalah teknik dokumentasi. 
Pengujian hipotesis pertama mengenai pengaruh pupuk, pestisida, tenaga kerja dan musim tanam terhadap tingkat produktivitas cabai merah di Kecamatan Wuluhan Kabupaten Jember di analisis menggunakan pendekatan fungsi produksi Cobb-Douglas dengan pengolahan data menggunakan aplikasi SPSS. Faktor-faktor yang mempengaruhi produksi secara matematis dapat diketahui dengan menggunakan fungsi produksi Cobb-douglas (Pindyck, 2009). Bentuk dari persamaan Cobb-Douglas dalam bentuk logaritma adalah sebagai berikut :

$\log \mathrm{Y}=\log \mathrm{b}_{0}+\mathrm{b}_{1} \log \mathrm{X}_{1}+\mathrm{b}_{2} \log \mathrm{X}_{2}+$ $b_{3} \log X_{3}+b_{4} \log D_{1}+e$

Keterangan:

$\mathrm{Y}=$ hasil produksi $(\mathrm{Kg})$

$\mathrm{X}_{1}=\operatorname{pupuk}(\mathrm{Kg})$

$\mathrm{X}_{2}=$ pestisida $(\mathrm{Rp})$

$\mathrm{X}_{3}=$ tenaga kerja $(\mathrm{HOK})$

$\mathrm{D}_{1}$ musim tanam $(\mathrm{DMT})=$

0 =cabai merah yang ditanam pada MH1

1 =cabai merah yang ditanam pada MK1

$\mathrm{b}_{0}=$ konstanta

$\mathrm{b}_{1}=$ koefisien regresi jumlah pupuk

$\mathrm{b}_{2}=$ koefisien regresi jumlah pestisida

$\mathrm{b}_{3}=$ koefisien regresi jumlah tenaga kerja

$\mathrm{b}_{4}=$ koefisien regresi DMT

e $=$ residual

Uji kelayakan model dilakukan dengan uji $\mathrm{F}$, uji t, dan koefisien determinasi (Nursiyono, 2016). Rumus uji F adalah sebagai berikut:

Keterangan:

$$
\mathrm{F}_{\text {hitung }}=\frac{\mathrm{SSE} /(\mathrm{k}-1)}{\mathrm{SSR} /(\mathrm{N}-\mathrm{k})}
$$

SSE = Sum Square of Error didapatkan dari tabel analysis of Varian (Anova)

SSR = Sum Square of regression didapatkan dari tabel anova

$\mathrm{K}=$ jumlah variabel bebas. Jumlah variabel bebas sama dengan jumlah parameter regresi dikurangi 1 .

$\mathrm{N} \quad=$ jumlah amatan.

Kriteria pengambilan keputusan pada tingkat signifikansi 5\%:

a. Jika Probabilitas < 0,05: $\mathrm{H}_{0}$ ditolak, maka penggunaan faktor-faktor produksi seperti pupuk, pestisida, tenaga kerja dan musim tanam secara bersama-sama berpengaruh nyata terhadap hasil produksi cabai merah di Kecamatan Wuluhan

Kabupaten Jember.

b. Jika Probabilitas > 0,05: $\mathrm{H}_{0}$ diterima, maka penggunaan faktor-faktor produksi seperti pupuk, pestisida, tenaga kerja dan musim tanam secara bersama-sama berpengaruh tidak nyata terhadap hasil produksi cabai merah di Kecamatan Wuluhan Kabupaten Jember.

Pengujian statistik menggunakan uji $\mathrm{t}$ dilakukan untuk mengetahui pengaruh variabel bebas secara parsial terhadap hasil produktivitas yang diterima. Tingkat signifikansi yang digunakan adalah $5 \%$. Rumus uji t adalah sebagai berikut:

Keterangan:

$$
t_{\text {hitung }}=\frac{\text { bi }}{\text { se (bi) }}
$$

$\widehat{\beta}_{\mathrm{k}} \quad$ : nilai estimasi dari parameter $\beta_{\mathrm{k}}$

se $\left(\widehat{\beta}_{\mathrm{k}}\right)$ : nilai standard of error dari

estimator $\beta_{\mathrm{k}}$

Kriteria pengambilan keputusan:

a. Jika probabilitas $<0,05, \mathrm{H}_{0}$ di tolak, maka penggunaan faktor produksi ke i secara parsial berpengaruh nyata terhadap hasil produksi cabai merah di Kecamatan Wuluhan Kabupaten Jember.

b. Jika probabilitas $>0,05, \mathrm{H}_{0}$ diterima, maka penggunaan faktor produksi ke i secara parsial berpengaruh tidak nyata terhadap hasil produksi cabai merah di Kecamatan Wuluhan Kabupaten Jember.

Koefisien determinasi menunjukkan besarnya persentase variasi seluruh variabel terikat yang dapat diterangkan oleh variabel bebas yang dihasilkan, sisanya diterangkan oleh variabel yang ada di luar model. Perhitungan Adj $\mathrm{R}^{2}$ yang semakin besar menjelaskan bahwa hubungan faktor produksi yang digunakan pada usahatani cabai merah semakin dekat terhadap produksi cabai merah. Rumus Adj $\mathrm{R}^{2}$ adalah sebagai berikut:

$$
\begin{aligned}
R^{2} & =1-\frac{\text { SSR }}{S S T} \\
\text { Adj } R^{2} & =1-\left(\frac{n-1}{n-k}\right)\left(1-R^{2}\right)
\end{aligned}
$$

Keterangan:

$$
\begin{array}{ll}
\text { SSR } & =\text { Sum Square of regression } \\
\text { SST } & =\text { Sum of Square total } \\
\text { N } & =\text { Jumlah amatan } \\
\text { K } & =\text { jumlah variabel bebas }
\end{array}
$$


Pengujian hipotesis kedua mengenai analisis efisiensi harga, efisiensi harga tercapai apabila nilai produk marginal (NPM) untuk suatu input atau masukan sama dengan harga input $(\mathrm{P})$ (Soekartawi dalam Darwanto, 2010). Secara matematis untuk mengetahui efisiensi harga untuk masing-masing faktor produksi dilakukan langkah-langkah sebagai berikut:

a. Menghitung nilai produk marjinal faktor produksi ke-i, secara matematis digunakan rumus:

Keterangan:

$$
\mathrm{NPM}_{\mathrm{xi}=} \frac{\text { bi.Y.P. }}{\mathrm{Xi}}
$$

$\mathrm{NPM}_{\mathrm{x} 1}=$ nilai produk marjinal faktor produksi ke-i

$\mathrm{Y}=$ produksi cabai merah $(\mathrm{Kg})$

$\mathrm{Xi} \quad=$ faktor produksi ke-i

bi = koefisien variabel ke-i

$\mathrm{P}_{\mathrm{y}}=$ harga produksi cabai merah $(\mathrm{Rp} / \mathrm{Kg})$

Nilai $Y, P_{y}, X i$ dan $P_{x i}$ diambil dari nilai ratarata.

b. Membandingkan $\mathrm{NPM}_{\mathrm{xi}}$ dengan $\mathrm{Px}_{\mathrm{i}}$ apakah terdapat perbedaan atau tidak terdapat perbedaan dengan menggunakan uji beda (Uji-t), secara matematis menggunakan rumus:

$$
\mathrm{t}=\frac{\overline{\mathrm{NPMx}_{\mathrm{i}}}-\overline{\mathrm{P}_{\mathrm{xi}}}}{\sqrt{\frac{\mathrm{S}_{\mathrm{NPMxi}}^{2}}{\mathrm{n}_{\mathrm{NPMxi}}}+\frac{\mathrm{S}_{\mathrm{Pxi}}^{2}}{n_{\mathrm{pxi}}}}}
$$

Keterangan:

$\overline{\mathrm{NPMxi}}=$ rata-rata nilai produk marjinal faktor produksi ke-i

$\overline{\mathrm{P}_{\mathrm{xi}}} \quad=$ rata-rata harga faktor produksi ke-i

$\mathrm{S}_{\mathrm{NPMxi}}=$ standart deviasi nilai produk marjinal faktor produksi ke-i

$\mathrm{S}_{\text {Pxi }}=$ standart deviasi harga faktor produksi ke-i

$\mathrm{n}_{\mathrm{NPMxi}}=\mathrm{n}_{\mathrm{pxi}}=$ Jumlah sampel petani cabai merah

Hipotesis:

$\mathrm{H}_{0}=$ Nilai produk marjinal faktor produksi ke-i berbeda tidak nyata dengan harga faktor produksi ke-i, penggunaan faktor produksi ke-i pada usahatani cabai merah di Kecamatan Wuluhan Kabupaten Jember mencapai efisiensi harga.

$\mathrm{H}_{1}=$ Nilai produk marjinal faktor produksi ke-i berbeda nyata dengan harga faktor produksi ke-i, penggunaan faktor produksi ke-i pada usahatani cabai merah di Kecamatan Wuluhan Kabupaten Jember tidak efisiensi harga.

Kriteria pengambilan keputusan pada tingkat signifikansi 5\%:

1) Jika probabilitas $>0,05$, maka $\mathrm{H}_{0}$ diterima dan $\mathrm{H}_{1}$ ditolak, artinya nilai produk marjinal faktor produksi ke-i berbeda tidak nyata dengan harga faktor produksi ke-i, penggunaan faktor produksi ke-i pada usahatani cabai merah di Kecamatan Wuluhan Kabupaten Jember mencapai efisiensi harga.

2) Jika probabilitas $<0,05$, maka $\mathrm{H}_{1}$ diterima dan $\mathrm{H}_{0}$ ditolak, artinya nilai produk marjinal faktor produksi ke-i berbeda nyata dengan harga faktor produksi ke-i, penggunaan faktor produksi ke-i pada usahatani cabai merah di Kecamatan Wuluhan Kabupaten Jember tidak efisiensi harga.

c. Apabila NPM faktor produksi ke-i berbeda nyata dengan harga faktor produksi ke-i maka dilakukan perhitungan:

Keterangan:

$$
\frac{\mathrm{NPM}_{\mathrm{xi}}}{\mathrm{P}_{\mathrm{xi}}}=\frac{\text { bi.Y.P. }}{\mathrm{Xi} \cdot \mathrm{P}_{\mathrm{xi}}}
$$

$\mathrm{NPM}_{\mathrm{x} 1}=$ nilai produk marjinal faktor produksi ke-i

$\mathrm{Y}=$ produksi cabai merah $(\mathrm{Kg})$

$\mathrm{Xi} \quad=$ faktor produksi ke-i

bi $\quad=$ koefisien variabel ke- $\mathrm{i}$

$\mathrm{P}_{\mathrm{y}} \quad=$ harga produksi cabai merah

$(\mathrm{Rp} / \mathrm{Kg})$

$\mathrm{Px}_{\mathrm{i}} \quad=$ harga faktor produksi ke-i

Nilai $\mathrm{Y}, \mathrm{P}_{\mathrm{y}}, \mathrm{Xi}$ dan $\mathrm{P}_{\mathrm{xi}}$ diambil dari nilai ratarata.

Kriteria pengambilan keputusan:

1) $\frac{\text { bi.Y.P. }}{X_{y}}>1$, penggunaan faktor produksi ke-i pada usahatani cabai merah tidak efisiensi dan perlu menambah penggunaan input.

2) $\frac{\text { bi.Y. } P_{y}}{X i . P_{i}}<1$, penggunaan faktor produksi ke-i pada usahatani cabai merah tidak efisiensi dan perlu mengurangi penggunaan input.

Pengujian hipotesis ketiga adalah mengenai efisiensi biaya, Efisiensi pada 
usahatani dapat dilihat dari tingkat profitabilitasnya dengan perhitungan $\mathrm{R} / \mathrm{C}$ ratio. $\mathrm{R} / \mathrm{C}$ ratio merupakan perbandingan antara total penerimaan dan total biaya yang dikeluarkan (Soekartawi, 1995). Secara matematis dituliskan sebagai berikut:

$\mathrm{R} / \mathrm{C}$ ratio $=\frac{\mathrm{TR}}{\mathrm{TC}}$

Kriteria keputusan:

a. $\mathrm{R} / \mathrm{C}>1$, artinya usahatani cabai merah di Kecamatan Wuluhan Kabupaten Jember menguntungkan dan layak untuk dikembangkan.

b. R/C < 1, artinya usahatani cabai merah di Kecamatan Wuluhan Kabupaten Jember mengalami kerugian dan tidak layak untuk dikembangkan.

c. $\mathrm{R} / \mathrm{C}=1$, artinya usahatani cabai merah di Kecamatan Wuluhan Kabupaten Jember dalam keadaan break even point.

\section{HASIL DAN PEMBAHASAN}

A. Faktor-Faktor yang Mempengaruhi Produktivitas Usahatani Cabai Merah di Kecamatan Wuluhan Kabupaten Jember

Uji kelayakan model (Goodness of Fit Model) meliputi uji $\mathrm{F}$, uji $\mathrm{t}$ dan uji adjusted $R^{2}$. Uji $\mathrm{F}$ digunakan untuk mengetahui seberapa besar pengaruh variabel bebas secara bersama-sama terhadap variabel terikat. Hasil uji F disajikan pada tabel 1.

Tabel 1. Analisis Varian Faktor-faktor yang Mempengaruhi Produktivitas Cabai Merah di Kecamatan Wuluhan Kabupaten Jember

\begin{tabular}{llrlll}
\hline Model & $\begin{array}{l}\text { Sum } \\
\text { of } \\
\text { Square }\end{array}$ & Df & $\begin{array}{l}\text { Mean } \\
\text { Suare }\end{array}$ & F & $\begin{array}{l}\text { Sig. } \\
(0,05)\end{array}$ \\
\hline Regression & 4,601 & 4 & 1,150 & 25,437 & $0,000^{\mathrm{b}}$ \\
Residual & 1,537 & 34 & 0,045 & & \\
Total & 6,138 & 38 & & & \\
\hline Adjusted & 0,720 & & & & \\
$\mathrm{R}^{2}$ & & & & \\
\hline Sumber: Data primer diolah (2017) &
\end{tabular}

Nilai F-hitung adalah sebesar 25,437 dengan tingkat signifikansi 0,000 . Nilai Ftabel diketahui sebesar 5,74, nilai F-hitung > nilai F-tabel dan nilai signifikansi $0,000<0,05$, oleh karena itu hipotesis 1 (H1) diterima maka penggunaan faktor-faktor produksi pupuk, pestisida, tenaga kerja dan musim tanam secara bersama-sama berpengaruh nyata terhadap produktivitas cabai merah di Kecamatan Wuluhan Kabupaten Jember.

Uji t dilakukan untuk mengetahui besarnya pengaruh masing-masing variabel bebas [pupuk $\left(\mathrm{X}_{1}\right)$, pestisida $\left(\mathrm{X}_{2}\right)$, tenaga kerja $\left(X_{3}\right)$ dan dummy musim tanam (D1)] terhadap variabel bebas yaitu tingkat produktivitas cabai merah di Kecamatan Wuluhan Kabupaten Jember. Hasil uji t dapat dilihat pada tabel 2 .

Tabel 2. Hasil uji t pada analisis regresi faktor-faktor yang mempengaruhi produktivitas cabai merah di Kecamatan Wuluhan Kabupaten Jember

\begin{tabular}{lrrrr}
\hline Variabel & \multicolumn{2}{c}{ Koefisien Std.Erro } & t-Hitung & Sig-t \\
& regresi & \multicolumn{1}{r}{ r } & & \\
\hline $\begin{array}{l}\text { pupuk } \\
\left(\mathrm{X}_{1}\right)\end{array}$ & 0,131 & 0,130 & 1,011 & 0,319 \\
$\begin{array}{l}\text { Pestisida } \\
\left(\mathrm{X}_{2}\right)\end{array}$ & 0,268 & 0,118 & 2,266 & $0,030^{*}$ \\
tenaga & 0,823 & 0,206 & 3,987 & $0,000^{*}$ \\
$\begin{array}{l}\text { kerja }\left(\mathrm{X}_{3}\right) \\
\text { dummy }\end{array}$ & 0,249 & 0,076 & 3,290 & $0,002^{*}$ \\
$\begin{array}{l}\text { musim } \\
\text { tanam } \\
(\mathrm{D} 1)\end{array}$ & & & & \\
Konstanta &,- 933 & 0,675 & $-1,382$ & 0,176 \\
\hline $\begin{array}{l}\text { t table }(\propto \\
=0,05)\end{array}$ & 2,032 & & & \\
\hline
\end{tabular}

Sumber : Data primer diolah (2017)

Keterangan: *) berpengaruh nyata pada taraf kepercayaan $95 \%$

Nilai adjusted $R^{2}$ sebesar 0,720 yang artinya bahwa $72 \%$ tingkat produktivitas cabai merah di Kecamatan Wuluhan Kabupaten Jember dapat dijelaskan dengan variabel pupuk $\left(\mathrm{X}_{1}\right)$, pestisida $\left(\mathrm{X}_{2}\right)$, tenaga kerja $\left(X_{3}\right)$ dan dummy musim tanam (D1), sedangkan $28 \%$ sisanya dijelaskan oleh variabel-variabel lain di luar model.

$\begin{aligned} \log Y= & 0,933+0,131 \log X_{1}+0,268 \log X_{2}+0,8 \\ & 23 \log X_{3}+0,249 \log D_{1}\end{aligned}$

Persamaan tersebut diestimasi dalam bentuk persamaan linier, untuk merubahnya kembali menjadi bentuk persamaan non inier maka dilakukan antilogaritma, sehingga bentuk persamaannya menjadi sebagai berikut:

$$
\mathrm{Y}=0,117 \mathrm{X}_{1}{ }^{0,131} \mathrm{X}_{2}{ }^{0,268} \mathrm{X}_{3}{ }^{0,823} \mathrm{D}_{1}{ }^{0,249}
$$


Nilai koefisien regresi menunjukkan besaran nilai elastisitas produksi. Daerah dengan elastisitas produksi $\geq 1$, artinya artinya bahwa penambahan faktor produksi sebesar $1 \%$ akan menyebabkan penambahan produksi lebih besar dari 1\%. Daerah 2, $0<\mathrm{EP}<1$, Pada daerah ini penambahan faktor produksi sebesar $1 \%$ akan menyebabkan penambahan produksi lebih dari $0 \%$ dan sampai kurang dari $1 \%$. Daerah 3, EP $\leq 0$, pada saat tingkat produksi $\mathrm{MP}=0, \mathrm{EP}=0$, penambahan faktor produksi sebesar $1 \%$ tidak akan menyebabkan perubahan pada produk total. (Hariyati,2007).

\section{a. $\quad$ Pupuk $\left(\mathrm{X}_{1}\right)$}

Koefisien regresi untuk faktor produksi pupuk $\left(\mathrm{X}_{1}\right)$ pada produktivitas cabai merah di Kecamatan Wuluhan Kabupaten Jember adalah sebesar 0,131. Besarnya koefisien tersebut menunjukkan bahwa setiap adanya penambahan pupuk sebesar $1 \%$ maka akan meningkatkan produktivitas sebesar $0,131 \%$ dalam keadaan (Cateris paribus) variabel bebas yang lain yang mempengaruhi produktivitas dianggap konstan. Nilai koefisien regresi menunjukkan besaran nilai elastisitas produksi atas penggunaan pupuk sebesar $0,131 \%$. Elastisitas produksi atas penggunaan pupuk kurang dari $1 \%$ yang berarti penambahan $1 \%$ pupuk menyebabkan total produksi terus mengalami peningkatan, namun tingkat penambahan produksi semakin lama semakin menurun disinilah berlaku hukum deminishing return. Penambahan pupuk masih terus dapat dilakukan selama proporsi tambahan produksi atas penambahan pupuk $1 \%$ belum mencapai 0 . Kondisi tersebut menunjukkan bahwa alokasi penggunaan pupuk berada pada daerah rasional.

\section{b. Pestisida $\left(\mathrm{X}_{2}\right)$}

Koefisien regresi untuk faktor produksi pestisida $\left(\mathrm{X}_{2}\right)$ pada produktivitas cabai merah di Kecamatan Wuluhan Kabupaten Jember adalah sebesar 0,268. Besarnya koefisien tersebut menunjukkan bahwa setiap adanya penambahan pestisida sebesar 1\% maka akan meningkatkan produktivitas sebesar $0,268 \%$ dalam keadaan (Cateris paribus) variabel bebas yang lain yang mempengaruhi produktivitas dianggap konstan. Nilai koefisien regresi menunjukkan besaran nilai elastisitas produksi atas penggunaan pestisida sebesar $0,268 \%$. Elastisitas produksi atas penggunaan pestisida kurang dari $1 \%$ yang berarti penambahan $1 \%$ pestisida menyebabkan total produksi terus mengalami peningkatan, namun tingkat penambahan produksi semakin lama semakin menurun disinilah berlaku hukum deminishing return. Penambahan pestisida masih terus dapat dilakukan selama proporsi tambahan produksi atas penambahan pestisida $1 \%$ belum mencapai 0 . Kondisi tersebut menunjukkan bahwa alokasi penggunaan pupuk berada pada daerah rasional.

\section{c. Tenaga kerja $\left(\mathrm{X}_{3}\right)$}

Koefisien regresi untuk faktor produksi tenaga kerja $\left(\mathrm{X}_{3}\right)$ pada produktivitas cabai merah di Kecamatan Wuluhan Kabupaten Jember adalah sebesar 0,823. Besarnya koefisien tersebut menunjukkan bahwa setiap adanya penambahan tenaga kerja sebesar $1 \%$ maka akan meningkatkan produktivitas sebesar $0,823 \%$ dalam keadaan (Cateris paribus) variabel bebas yang lain yang mempengaruhi produktivitas dianggap konstan.

Nilai koefisien regresi menunjukkan besaran nilai elastisitas produksi atas penggunaan tenaga kerja sebesar 0,823\%. Elastisitas produksi atas penggunaan tenaga kerja kurang dari $1 \%$ yang berarti penambahan $1 \%$ tenaga kerja menyebabkan total produksi terus mengalami peningkatan, namun tingkat penambahan produksi semakin lama semakin menurun disinilah berlaku hukum deminishing return. Penambahan penggunaan tenaga kerja masih terus dapat dilakukan selama proporsi produksi atas penambahan tenaga kerja $1 \%$ belum mencapai 0 . Kondisi tersebut menunjukkan bahwa alokasi penggunaan pupuk berada pada daerah rasional.

\section{d. Dummy musim tanam}

Koefisien regresi untuk dummy musim tanam $\left(\mathrm{D}_{1}\right)$ terhadap tingkat produktivitas cabai merah di Kecamatan Wuluhan Kabupaten Jember adalah sebesar 0,249 . Besarnya nilai koefisien tersebut 
menunjukkan bahwa penanaman tanaman cabai merah pada musim kering akan menyebabkan tingkat produktivitas yang lebih tinggi $0,249 \%$ dibandingkan penanaman tanaman cabai yang dilakukan pada saat musim hujan.

\section{B. Efisiensi harga penggunaan faktor-} faktor produksi pada usahatani cabai merah di Kecamatan Wuluhan Kabupaten Jember

Efisiensi penggunaan masing-masing faktor produksi pupuk, pestisida dan tenaga kerja pada usahatani cabai merah di Kecamatan Wuluhan Kabupaten Jember mencapai efisiensi ekonomi apabila nilai produk marjinal masing-masing faktor produksi tersebut sama dengan harga faktor produksinya. Tingkat rata-rata produksi cabai merah / Ha di Kecamatan Wuluhan Kabupaten Jember adalah $6.688 \mathrm{Kg}$ dan harga rata-rata hasil produksi cabai merah adalah sebesar $\mathrm{Rp}$ 16.279. Besarnya rasio $\mathrm{NPMx}_{\mathrm{i}}$ dengan $\mathrm{Px}_{\mathrm{i}}$ dan t-hitung dari hasil analisis uji beda masing-masing faktor produksi yang digunakan disajikan pada tabel 3.

Keterangan:

$\mathrm{Bi}=$ Koefisien regresi variabel ke

$\mathrm{X}_{\mathrm{i}}=$ Total penggunaan faktor produksi $\mathrm{ke}_{\mathrm{i}}$

$\mathrm{Px}_{\mathrm{i}} \quad=$ Harga faktor produksi $\mathrm{ke}_{\mathrm{i}}(\mathrm{Rp})$

$\mathrm{NPMx}_{\mathrm{i}}=$ Nilai produk marginal faktor produksi $\mathrm{ke}_{\mathrm{i}}$

$\mathrm{NPMx}_{\mathrm{i}} / \mathrm{Px}=$ efisiensi harga faktor produksi $\mathrm{ke}_{\mathrm{i}}$ a. Pupuk

Nilai t-hitung dari hasil analisis uji beda dengan uji $\mathrm{t}$ antara nilai produk marginal pupuk dengan harga pupuk 2,884> t-tabel 2,042 dan nilai signifikansi $0,006<0,05$ menunjukkan bahwa $\mathrm{H} 1$ diterima, artinya terdapat perbedaan nyata antara nilai produk marginal pupuk dengan harga pupuk. Rasio atau perbandingan antara nilai produk marginal pupuk dengan harga pupuk adalah 1,84 yang mana nilai tersebut lebih dari satu artinya bahwa penggunaan faktor produksi pupuk pada usahatani cabai merah di Kecamatan Wuluhan Kabupaten Jember belum mencapai efisiensi harga sehingga untuk mencapai kondisi efisiensi harga maka diperlukan penambahan penggunaan pupuk pada proses usahataninya. Nilai produk marginal pupuk adalah 4164 yang menunjukkan bahwa setiap penambahan satu satuan faktor produksi pupuk maka akan meningkatkan tambahan penerimaan sebesar Rp 4.164.

\section{b. Pestisida}

Faktor produksi pestisida pada penelitian ini tidak dilakukan analisi uji beda antara nilai produk marjinal pestisida dengan harga pestisida karena pestisida yang digunakan oleh petani cabai merah di Kecamatan Wuluhan Kabupaten Jember ada yang berbentuk cair dan ada yang berbentuk padat sehingga untuk menyamakan satuan digunakan satuan berupa rupiah, karena hal tesebut maka pada tabel 3 tidak muncul nilai $\mathrm{X}$ pestisida dan $\mathrm{P}_{\text {pestisida }}$ yang diketahui adalah biaya total penggunaan faktor produksi pestisida yaitu sebesar Rp 5.906.966. Perhitungan

Tabel 3. Perbandingan nilai $\mathrm{NPMx}_{\mathrm{i}}$ dengan $\mathrm{Px}_{\mathrm{i}}$ dan t-hitung dari hasil analisis uji beda masingmasing faktor produksi pada usahatani cabai merah di Kecamatan Wuluhan Kabupaten Jember

\begin{tabular}{llccrrrrc}
\hline No. & \multicolumn{1}{c}{ Variabel } & $\mathrm{Bi}$ & $\mathrm{Xi}$ & $\mathrm{Px}_{\mathrm{i}}(\mathrm{Rp})$ & $\mathrm{NPMx}_{\mathrm{i}}$ & $\mathrm{NPMx}_{\mathrm{i}} / \mathrm{Px}_{\mathrm{i}}$ & t-hitung & Sig \\
\hline 1 & Pupuk (Kg) & 0,131 & 3425 & 2.261 & 4164 & 1,84 & 2,884 & 0,006 \\
2 & Pestisida (Rp) & 0,268 & & & & 4,31 & & \\
3 & Tenaga kerja (HOK) & 0,823 & \multirow{2}{*}{778} & 43.971 & 115.196 & 2,62 & 6,969 & 0,000 \\
\hline
\end{tabular}

$\mathrm{t}$ tabel $(\alpha=0,05) 2,042$

Sumber: Data Primer diolah (2017) 
efisiensi harga $(\mathrm{EH})$ faktor produksi pestisida adalah sebagai berikut:

$$
\begin{aligned}
\mathrm{EH}_{\text {pestisida }} & =\frac{\mathrm{NPM} \text { pestisida }}{\mathrm{P} \text { pestisida }} \\
\frac{0,26.6688 .16279}{5906966} & =\frac{\text { bi.Y.Py }}{\mathrm{x} \_ \text {pestisida.P_pestisida }}=
\end{aligned}
$$

Rasio atau perbandingan antara nilai produk marginal pestisida dengan harga pestisida adalah 4,31 yang mana nilai tersebut lebih dari satu artinya bahwa penggunaan faktor produksi pestisida pada usahatani cabai merah di Kecamatan Wuluhan Kabupaten Jember belum mencapai efisiensi harga sehingga untuk mencapai kondisi efisiensi harga maka diperlukan penambahan penggunaan pestisida pada proses usahataninya.

\section{c. Tenaga Kerja}

Nilai t-hitung dari hasil analisis uji beda dengan uji $t$ antara nilai produk marginal tenaga kerja dengan upah tenaga kerja 6,696 > t-tabel 2,042 dan nilai signifikansi $0,000<0,05$ menunjukkan bahwa $\mathrm{H} 0$ ditolak artinya terdapat perbedaan nyata antara nilai produk marginal tenaga kerja dengan upah tenaga kerja. Rasio atau perbandingan antara nilai produk marginal tenaga kerja dengan upah tenaga kerja adalah 2,62 yang mana nilai tersebut lebih dari satu artinya bahwa penggunaan faktor produksi tenaga kerja pada usahatani cabai merah di Kecamatan Wuluhan Kabupaten Jember belum mencapai efisiensi harga sehingga untuk mencapai kondisi efisiensi harga maka diperlukan penambahan penggunaan faktor produksi tenaga kerja pada proses usahataninya. Nilai produk marginal tenaga kerja adalah 115196 yang menunjukkan bahwa setiap penambahan satu satuan faktor produksi tenaga kerja maka akan meningkatkan tambahan penerimaan sebesar Rp 115.196.

\section{Efisiensi biaya pada usahatani cabai merah di Kecamatan Wuluhan Kabupaten Jember}

Tingkat profitabilitas pada usahatani cabai merah di Kecamatan Wuluhan Kabupaten Jember diketahui dengan menghitung $\mathrm{R} / \mathrm{C}$ ratio caranya dengan menghitung ratio antara total penerimaan dengan total biaya yang dikeluarkan. Biaya yang dikeluarkan pada usahatani cabai merah di Kecamatan Wuluhan Kabupaten Jember meliputi biaya tetap dan biaya variabel. Rincian kebutuhan biaya disajikan pada tabel 4.

Tabel 4. Rincian Biaya dan Persentase Biaya pada Usahatani Cabai Merah di Kecamatan Wuluhan Kabupaten

\begin{tabular}{|c|c|c|c|}
\hline No. & Kebutuhan biaya & $\begin{array}{c}\text { Total Biaya } \\
\text { (Rp) }\end{array}$ & $\begin{array}{c}\text { Persent } \\
\text { ase } \\
(\%)\end{array}$ \\
\hline \multirow[t]{4}{*}{1.} & Biaya tetap & & \\
\hline & Biaya Sewa lahan & 7.494.872 & 10,98 \\
\hline & $\begin{array}{l}\text { Biaya Penyusutan } \\
\text { alat }\end{array}$ & 3.038 .459 & 4,45 \\
\hline & $\begin{array}{l}\text { Total biaya tetap } \\
\text { (TFC) }\end{array}$ & 10.533 .331 & 15,43 \\
\hline \multirow[t]{9}{*}{2.} & Biaya Variabel & & \\
\hline & Biaya Bibit/benih & 3.125 .641 & 4,58 \\
\hline & Biaya Pupuk & 6.780 .839 & 9,93 \\
\hline & Biaya Pestisida & 5.906 .966 & 8,65 \\
\hline & Biaya Tenaga & & \\
\hline & kerja & 33.969 .701 & 49,76 \\
\hline & Biaya lain-lain & 7.948 .528 & 11,64 \\
\hline & $\begin{array}{l}\text { Total biaya } \\
\text { variabel (TVC) }\end{array}$ & 57.731 .675 & 84,57 \\
\hline & Biaya total (TC) & 68.265.006 & 100 \\
\hline
\end{tabular}
Jember

Sumber: Data primer diolah (2017)

Berdasarkan tabel 4 dapat dilihat bahwa total biaya yang dikeluarkan petani pada usahatani cabai merah di Kecamatan Wuluhan Kabupaten Jember adalah sebesar Rp. 68.265.006 yang terdiri dari pengeluaran biaya tetap dan biaya variabel. Pengeluaran untuk total biaya tetap adalah sebesar $\mathrm{Rp}$ 10.533.331 yang terdiri dari pengeluaran untuk biaya sewa lahan sebesar Rp 7.494.872 atau $10,98 \%$ dari total biaya dan biaya penyusutan alat sebesar 3.038 .459 atau $4,45 \%$ dari total biaya. Biaya variabel terdiri dari biaya bibit/benih, biaya pupuk, biaya pestisida, biaya tenaga kerja, dan biaya lain-lain. Biaya bibit/benih merupakan biaya terkecil yang dikeluarkan dibandingkan dengan biaya variabel-variabel yang lain. Biaya variabel tertinggi yang dikeluarkan petani adalah biaya untuk tenaga kerja sebesar Rp 33.969.701 atau $49,76 \%$ dari total biaya yang dikeluarkan.

Nilai efisiensi biaya usahatani cabai merah di Kecamatan Wuluhan Kabupaten 
Jember dilakukan perhitungan $\mathrm{R} / \mathrm{C}$ ratio. Secara rinci analisis efisiensi biaya cabai merah di Kecamatan Wuluhan Kabupaten Jember disajikan pada tabel 5 .

Tabel 5. Analisis Efisiensi Biaya Usahatani Cabai Merah di Kecamatan Wuluhan Kabupaten Jember

\begin{tabular}{|c|c|c|c|}
\hline No. & Uraian & Satuan & Total \\
\hline 1. & $\begin{array}{l}\text { Harga produksi } \\
\text { cabai merah } \\
(\mathrm{Rp} / \mathrm{Kg})\end{array}$ & $\mathrm{Rp}$ & 16.279 \\
\hline 2. & Total produksi & $\mathrm{Kg}$ & 6.688 \\
\hline 3. & $\begin{array}{l}\text { Total } \\
\text { penerimaan } \\
\text { (TR) }\end{array}$ & $\mathbf{R p}$ & 108.873 .952 \\
\hline 4. & $\begin{array}{l}\text { Biaya tetap } \\
\text { (TFC) }\end{array}$ & $\mathrm{Rp}$ & 10.533 .331 \\
\hline 5. & $\begin{array}{l}\text { Biaya Variabel } \\
\text { (TVC) }\end{array}$ & $\mathrm{Rp}$ & 57.731 .675 \\
\hline $\begin{array}{l}6 . \\
7 .\end{array}$ & $\begin{array}{l}\text { Biaya total }(\mathrm{TC}) \\
\text { Total } \\
\text { pendapatan }(\pi)\end{array}$ & $\begin{array}{l}\text { Rp } \\
\text { Rp }\end{array}$ & $\begin{array}{l}68.265 .006 \\
40.608 .946\end{array}$ \\
\hline
\end{tabular}

Sumber: data primer diolah (2017)

Berdasarkan tabel 5 dapat dilihat bahwa total penerimaan usahatani cabai merah di Kecamatan Wuluhan Kabupaten Jember adalah sebesar Rp 108.873.952 yang dihasilkan dari perkalian antara harga produksi cabai merah sebesar Rp 16.279 dengan total jumlah produksi sebesar 6.688 Kg. Biaya total sebesar Rp 68.265.006 dari penjumlahan total biaya tetap sebesar $\mathrm{Rp}$ 10.533.331 dengan total biaya variabel sebesar Rp 57.731.675. R/C ratio sebesar 1,59>1 menunjukkan bahwa usahatani cabai merah yang dijalankan di Kecamatan Wuluhan Kabupaten Jember menguntungkan atau efisien dalam penganggaran biaya produksi sehingga usahatani tersebut layak untuk diusahakan. $\mathrm{R} / \mathrm{C}$ ratio sebesar 1,59 artinya bahwa setiap pengeluaran biaya $\mathrm{Rp} 1$ akan menghasilkan Rp 1,59.

\section{KESIMPULAN}

Berdasarkan hasil analisis menunjukkan bahwa faktor-faktor produksi pupuk, pestisida, tenaga kerja dan Dummy musim tanam secara bersama-sama berpengaruh nyata terhadap produktivitas cabai merah di Kecamatan Wuluhan Kabupaten Jember. Secara parsial faktor Pupuk, pestisida, tenaga kerja, dan musim tanam memberikan pengaruh positif terhadap produktivitas dengan koefisien masing-masing sebesar $0,131,0,268,0,823$, dan 0,249.

Penggunaan faktor produksi pupuk, pestisida dan tenaga kerja pada usahatani cabai merah di Kecamatan Wuluhan Kabupaten Jember secara harga tidak efisien. Nilai efisiensi harga pupuk adalah $1,84>1$, pestisida $4,31>1$, dan tenaga kerja $2,62>1$. Nilai efisiensi harga yang lebih dari satu untuk faktor produksi pupuk, pestisida, dan tenaga kerja menunjukkan bahwa perlu dilakukan adanya penambahan faktor produksi untuk mencapai efisiensi harga.

Perhitungan R/C ratio pada usahatani cabai merah di Kecamatan Wuluhan Kabupaten Jember diperoleh hasil 1,59 yang menunjukkan bahwa penggunaan biaya pada usahatani cabai merah di Kecamatan Wuluhan Kabupaten Jember adalah efisien dan usahatani tersebut menguntungkan serta layak untuk dijalankan.

Bagi petani, sebaiknya melakukan peningkatan penggunaan faktor produksi tenaga kerja, pestisida dan pupuk agar tercapai penggunaan faktor produksi yang efisien secara harga, hal ini karena berdasarkan hasil penelitian menunjukkan bahwa masing-masing nilai efisiensi harga untuk masing-masing faktor produksi tersebut adalah 2,62, 4,31 dan 1,84 yang masing-masing nilainya adalah lebih dari satu, artinya diperlukan penambahan penggunaan faktor produksi agar tercapai kondisi penggunaan faktor produksi yang efisien secara harga.

Bagi pemerintah, sebaiknya menjadikan Kecamatan Wuluhan sebagai Wilayah sentra pengembangan cabai merah yang ada di Kabupaten Jember melihat bahwa kondisi geografis Kecamatan Wuluhan sesuai dengan syarat tumbuh cabai merah dan usahatani cabai merah yang diusahakan memberikan keuntungan atau dengan kata lain layak 
untuk diusahakan ditunjukkan dengan hasil analisis R/C ratio sebesar 1,59.

\section{DAFTAR PUSTAKA}

Anwarudin, M.J, Apri L.S, Aditia M, dan Yusdar H.2015. Dinamika Produksi dan Volatilitas Harga Cabai: Antisipasi Strategi dan Kebijakan Pengembangan. Pengembangan Inovasi Pertanian, 8(1)33-42.

Azzamy.2016. Tips Budidaya Menanam Cabai saat musim Hujan. [Serial Online]. Mitalom.com, 19 Mei 2017.

Badan Pusat Statistik Kabupaten Jember. 2016. Kabupaten Jember dalam Angka. Jember: Badan Pusat Statistik Kabupaten Jember.

Hariyati, Yuli. 2007. Ekonomi Mikro. Jakarta: CSS.

Imtiyaz, Hilal, Barlian H.P, Nurul H. 2017. Sistem Pendukung Keputusan Budidaya Tanaman Cabai Berdasarkan Prediksi Curah Hujan.J-ptiik, 1(9):733-738.

Martono, Nanang. 2015. Metode Penelitian Sosial. Jakarta: PT. Raja Grasindo Prasindo.

Nauly, Dahlia. 2016. Fluktuasi dan Disparitas Harga Cabai di Indonesia. Agrosains dan Teknologi, 1(1): 57-69.

Nursiyono, Joko Ade dan P.P.H. Nadaek. 2016. Setetes Ilmu Regresi Linier. Malang: Media Nusa Creatif.

Pindyck, Robert S. 2009. Mikroekonomi. Jakarta: Indeks.

Pranata, Gd. Wisnu, Lien D. 2016. Faktorfaktor yang Mempengaruhi Produksi Usahatani Cabai Merah Kriting di Desa Bulupountu Jaya Kecamatan Sigi Biromaru Kabupaten Sigi. J. Agroland, 23(1): 11-19.

Siahaan, Daniel S. 2015. Analisis Efisiensi Penggunaan Faktor Produksi Usahatani
Cabai Merah (Capsicum Annum L.).Skripsi. Medan: Agribisnis Fakultas Pertanian Universitas Sumatera Utara.Soekartawi. 1995. Analisis Usahatani. Jakarta: UI Press.

Soekartawi. 1995. Analisis Usahatani. Jakarta: UI Press.

Soekartawi. 2013. Agribisnis Teori dan Aplikasinya. Jakarta: Rajawali Press.

Surya, T.A. 2015. Pengendalian Inflasi Komoditas Pangan Menjelang Blan Ramadhan. Info Singkat Ekonomi dan Kebijakan Publik, 8(11): 13-16.

Triwidiyaningsih, Maharani. 2011. Analisis Efisiensi Ekonomi Penggunaan faktorfaktor Produksi pada Usahatani Cabai Merah di Kabupaten Bantul.Skripsi.Surakarta: Fakultas pertanian Universitas Sebelas Maret. 